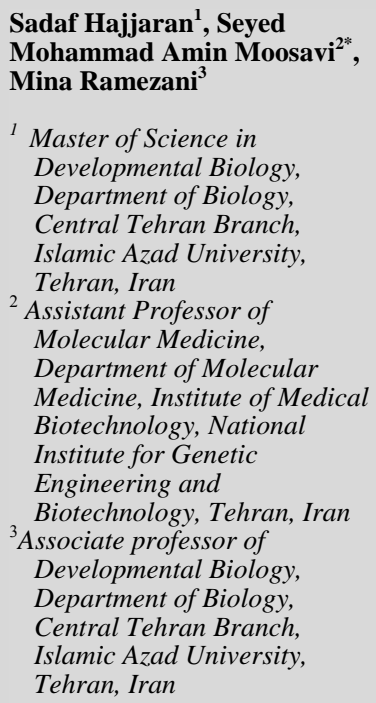

Tel: 0912- 0931693

E-mail: a-moosavi@nigeb.ac.ir

\section{Evaluating Effects of Nitrogen-Doped-Titanium Dioxide in Photodynamic Therapy of Breast Cancer MCF-7 Cells}

Received:1 Oct 2017 ; Accepted:23 Oct 2017

\section{Abstract}

Background: Titanium dioxide $\left(\mathrm{TiO}_{2}\right)$ nanoparticles (NPs) activated by ultraviolent light (UV) have been recently proposed as a nano-photosensitizer (PS) for cancer therapy. However, because adverse effects of UV light, other dopped- $\mathrm{TiO}_{2} \mathrm{NPs}$ with ability of activation by safe light sources, such as visible light, have been recommended for photodynamic therapy (PDT) purposes. The aim of this study is to evaluate effects of photodynamic N-TiO ${ }_{2}$ NPs in MCF-7 cell line as human epithelial breast cancer cell line. Methods: MCF-7 cells were treated with different concentrations of $\mathrm{N}-\mathrm{TiO}_{2} \mathrm{NPs}_{\mathrm{s}}$ and a visible light source was used for their photocatalytic activation. Trypan blue staining was performed to investigate the rate of cell viability and cell growth at $24 \mathrm{~h}$ and $48 \mathrm{~h}$ upon irradiation. Acridine Orange/Ethidium Bromide (AO/EtBr) staining and deoxyribonucleic acid (DNA)-laddering assay were used for detecting the mode of cell death.

Results: Treatment of MCF-7 cells with $\mathrm{N}_{-}-\mathrm{TiO}_{2} \mathrm{NPs}$, up to $100 \mu \mathrm{g} / \mathrm{ml}$ was inert and did not significantly affect growth and viability. However, with the increasing at concentrations of NP, the rate of cell death increased considerably upon visible-light irradiation. The $\mathrm{AO} / \mathrm{EtBr}$ double staining and DNA-ladder assay showed that the mode of cell death induced by photodynamic $\mathrm{N}-\mathrm{TiO}_{2} \mathrm{NPs}$ is mostly through apoptosis.

Conclusion: $\mathrm{N}^{-\mathrm{TiO}_{2}} \mathrm{NPs}$ in conjugation with visible-light may be proposed as a safe approach for PDT of breast cancer cells.

Keywords: Apoptosis, Breast Cancer, Nanoparticles, Nitrogen-doped, Titanium dioxide 


\section{بر رسى تأثيرات نانوذرات تيتانيوم دىاكسيد دويه شده با نيتروزن در

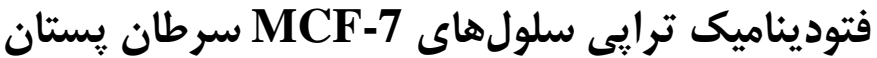

تاريخ دريافت مقاله: 99/V/9 ؛ تاريخ بذيرش: 99/N/1

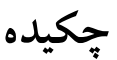

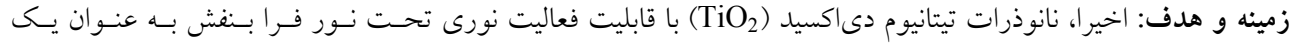

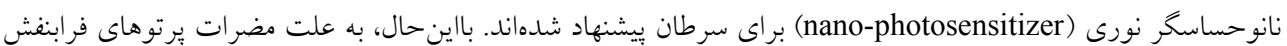

نانوذرات ارتقا يافته ديخرى بريايهى

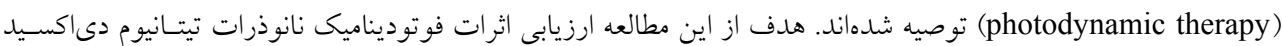

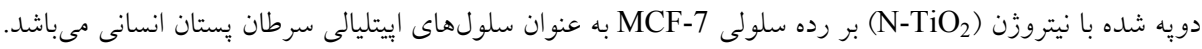
مواد و روش ها: سلولهاى MCF-7 با غلظتهاى مختلف از نانوذرات N-TiO تيمار شده و به منظور تحريـك فعاليـت

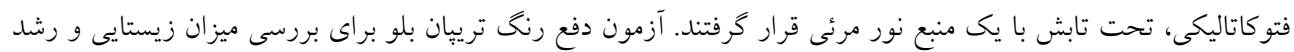

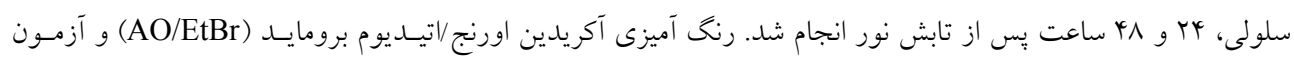

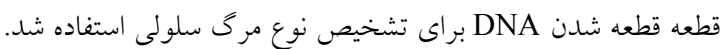

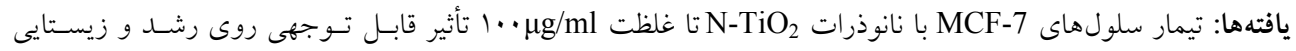

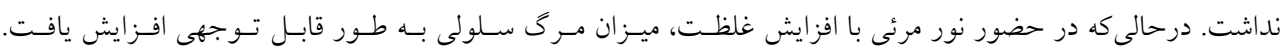

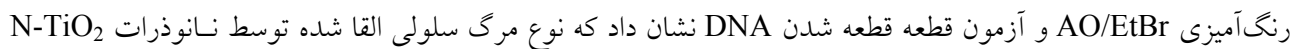
بر اساس PDT عمدتاً از طريق آيويتوز است

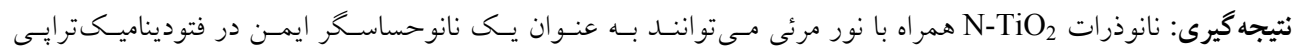
سلولهاى سرطانى يستان بيشنهاد شود. كلمات كليدى: آيويتوز، سرطان يستان، نانوذرات، دويه كردن با نيتروزن، تيتانيوم دياكسيد

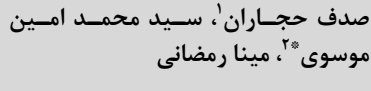

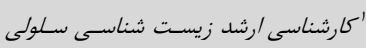

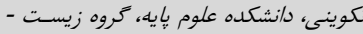

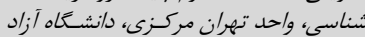

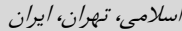

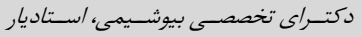

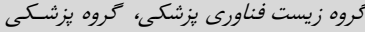

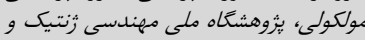

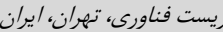

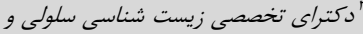

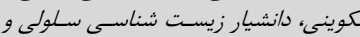

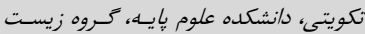

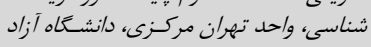
اسلامى، تهران، /يران

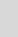




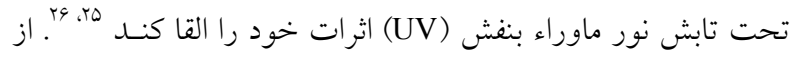

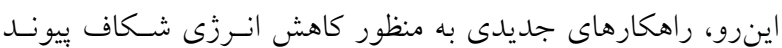
اين نانوذره و فعاليتش در حضور نور مرئى به كار كرفته شده است.

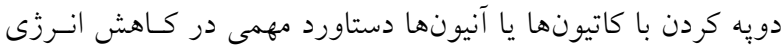
شكاف باند نانوذرات TiO

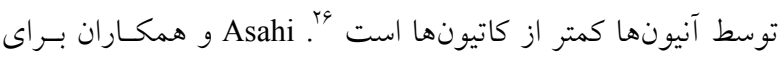

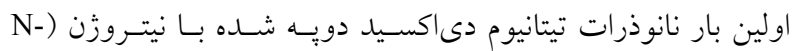
نسبت به ديخـر

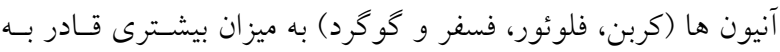

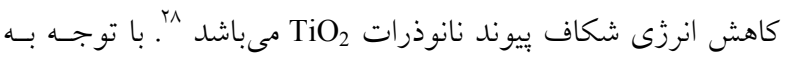

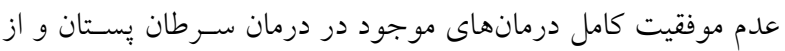

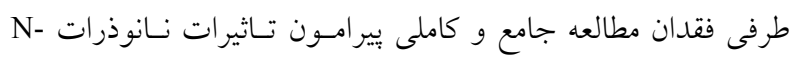
بر روى مهار رشد و مرگ سلولى سلولهاى سـرطان يستان، هدف از اين مطالعه بررسى تـاثيرات نـانوذرات تيتـانيوم دىاكسيد

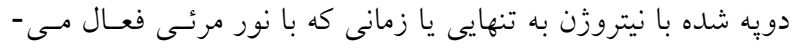

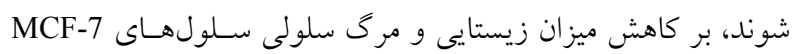
به عنوان سلولهاى اييتليال سرطان يستان انسانى است.

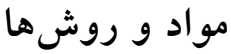
اين مطالعه از نوع تجربى - آزمايشگاهى بوده است.

East ) Biosera تهيـه شـــه از شـركت DMEM مشــ

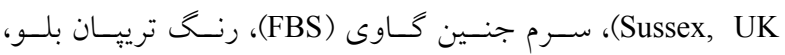
تريس(Tris-HCl)، آكريدين اورنـج/اتيــيوم برومايــ(EtBr/AO) و اتيلن دى آمين تترا استيك اسيد (EDTA) از شركت سيخما آمريكـا تهيـهـ شــند. يـودر 99\% و اوره به ترتيب از شركتهاى Coteix كره جنسوبى و Merck آلمان تهيه شدند. ينىسيلين و استريتومايسين و همين طور يروتئينـاز

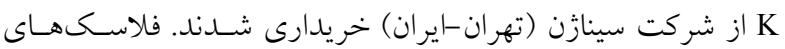
كشت سلول از شركت SPL Life Science (كره جنوبى) تهيه شدند.
سرطان يك مشكل اساسى در ايران و ديخـــ كشـورهاى جهان است. به طور تقريبى \&| ميليون مورد جديد سـرطان و ك/T ميليسون مرك ناشى از سرطان ساليانه به صـورت جهانى اتفـاق مسى افتـــ '.

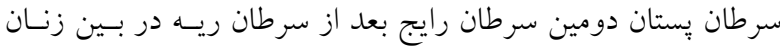

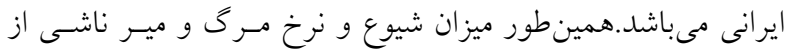

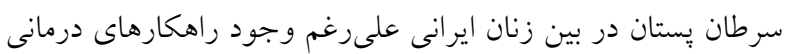

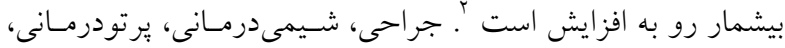
هورمون درمانى و يا تركيب اين موارد از جمله معمولتسرين روش -

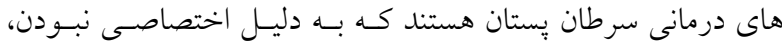
عوارض جانبى شديدى ايجاد مس كنـــ؛ همجنـين باعـث متاستاز،

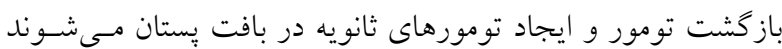

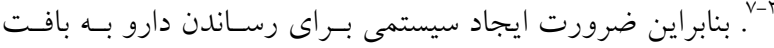
تومورى بدون عوارض جانبى احساس مىشود. نـانوتكنولوزى يـــ شاخه به سرعت در حال رشد است كه به طور گستردهاى در زمينههاى مختلف از جمله يزشكى مورد توجه قرار كرفته است و نشـان

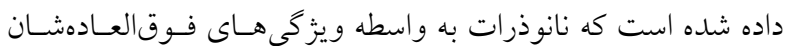

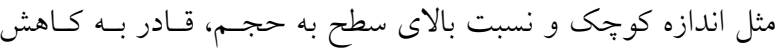

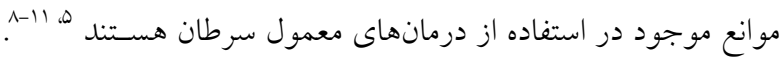

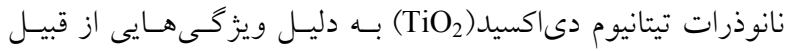
غيرسمى بودن، جذب نورى فـوقالعـاده، هزينـه هـايين و بايــارى

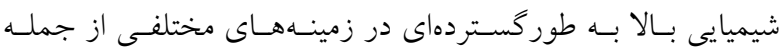
يز شكى مورد توجه قرار كرفتهاند ". "

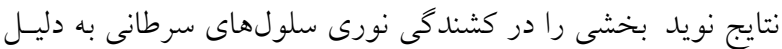

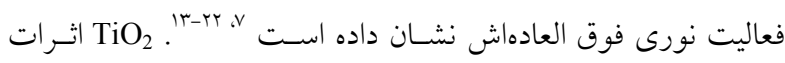

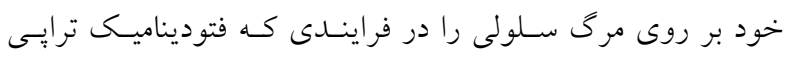

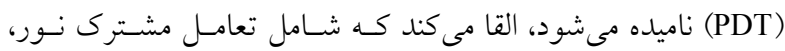
حساس گر نورى (PS) و جفت الكترون- حفره است كـه منجـر بـهـ ايجاد كونههاى اكسيزن فعال (ROS) و در نتيجه سبب مرك سلولى

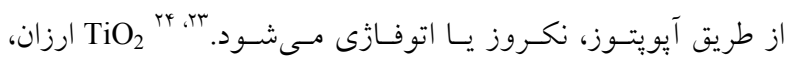

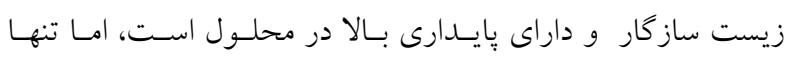

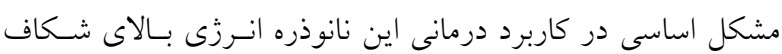
يبيوند آن (r/r الكترون ولت) است كه باعث مىشود اين نيمه رسانا 
شده تحت تابش لامب زنون •ها وات (به عنوان منبع نور مرئى) بـهـ

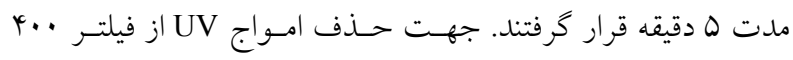
نانو متر استفاده شد.

\section{بررسى رشد و زيستايى سلولها با استفاده از آزمون دفـع رنــ} تريّان بلو

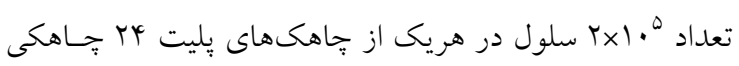

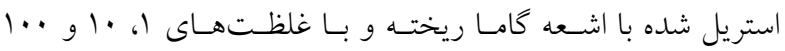
ميكروگرم بر ميلى ليتر از نانوذرات N-TiO در دو گروه تيمار شدند.

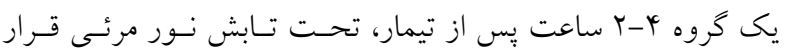

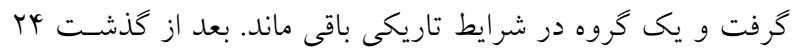
و Y باعت از تيمار تعداد سلولهاى هر جاهك بـا اسـتفاده از لام

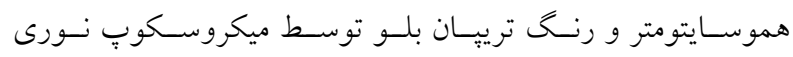

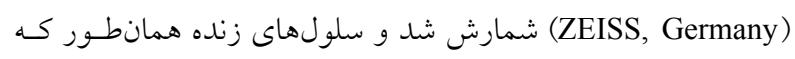

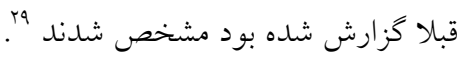

\section{بررسى ريخت شناسى سلولها}

به منظور بررسى تغييرات ايجاد شده در سلولهاى MCF-7 بعد از تيمار با غلظتهايى كه باعث \% م مهار رشــ مسىشـوند، تعـداد

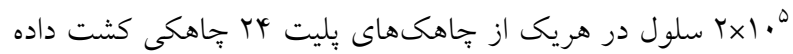

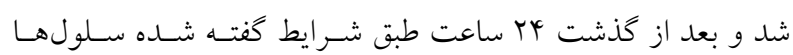
تيمار شدند و بعد از كذشت مدت زمان مورد نظر، تغييرات ريخــت شناسى توسط ميكروسـكوبٍ نـورى معكـوس(Olympus, Japan) بررسى شد.

بر رسى مرگ سلولى با استفاده از ميكروسكوب فلورسانس

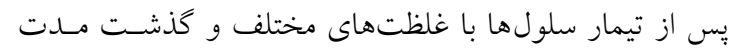

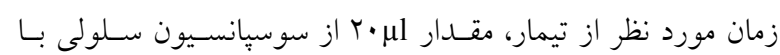

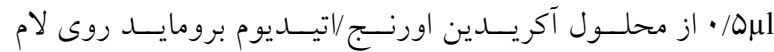

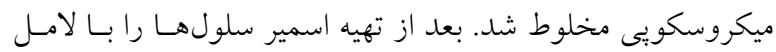
بوشانده و سبِ بِا ميكروسكوبٍ فلورسنت مشاهده شد.
روش بررسى

آمادهسازى و تعيين مشخصات نانوذرات آمادهسازى نانوذرات N-TiO به طور كامل در مطالعه قبلى مـا

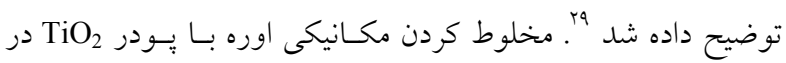

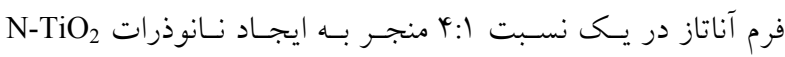

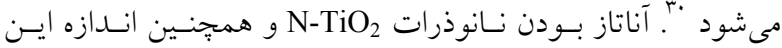
نانوذرات توسط ميكروسكوب الكترونسى گـزاره (TEM 120, ) تاييد شد. انــازمى نـانوذرات از طريـق روش (Philips, Germany براكندكى ديناميكى نور (DLS) مشـخص شــ كـه توسـط دســاه شetaplus) DLS منظور ابتدا استوك lmg/ml از نانوذرات N-TiO در آب ديونيزه يا محيط كشت (با يا بدون FBS) تهيه شد. سبس غلظتهـاى . .1-1 ميكرو گرم بر ميلى ليتر از نانوذرات N-TiO در آب ديسـونيزه، محسيط

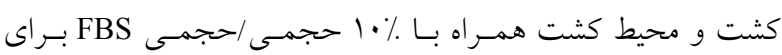
آناليزهاى DLS تهيه شدند.

كشت سلول

MCF- سلولهاى إيتليالى سرطان يُتان انسانى، ردهى سـلولى 7، از بانكى سلولى ايران (انستيتو پِاستور ايران) تهيه شــــ در محسيط

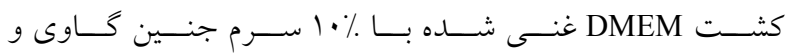
أنتـى بيوتيــهــاى استريتومايسـين ( و 9 9 و در انكوباتور حاوى ها درصسد

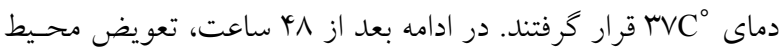
كشت و باساز به منظور انجام تستهاى بعدى انجام شد.

\section{تيمار سلولها با نانوذرات N-TiO}

بعد از Y Tاعت، هنكامى كه سلولها به تـراكم \% 1. رسـيدند،

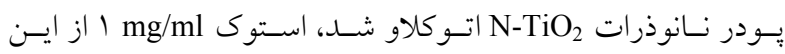
نانوذرات در محيط كشت DMEM ساخته شــ و تحــت نوسـانات اولتراسونيك قرار گرفت در ادامه براى حسذف تجمعـات نـانوذرات • ا درصد FBS به استوك نانوذرات اضافه شد و غلظتهــاى 1، · 1.

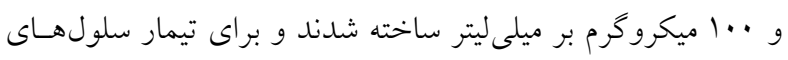

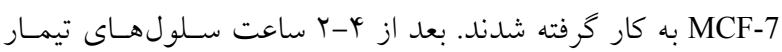


همانطور كه در شكل ا مشخص است، مورفولـوزى نـانوذرات

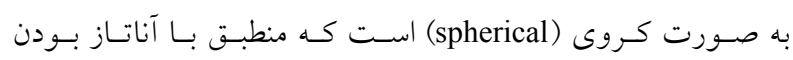

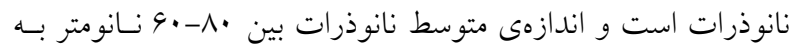

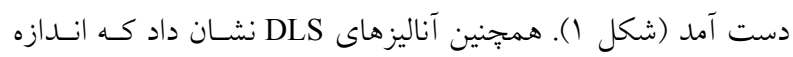

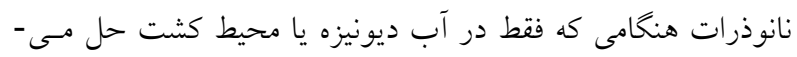

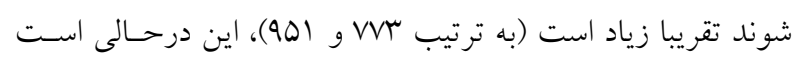

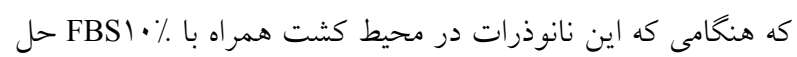

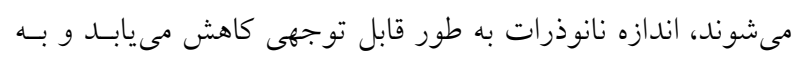
حدود سايز اوليه (MIM (TI) مىرسد (جدول ()).

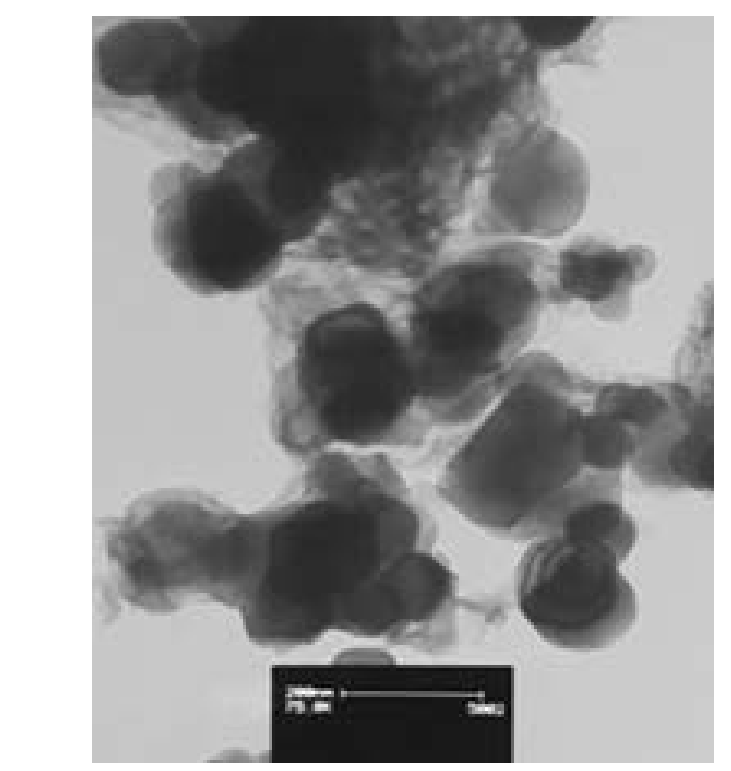

شكل ا: تعيين مشخصات نانوذرات N-TiO . تصوير ميكروسكو

الكترونى از نانوذرات
آزمون قطعه قطعه شدن DNA

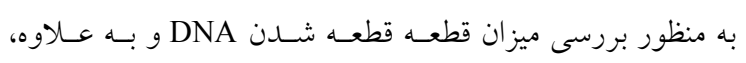

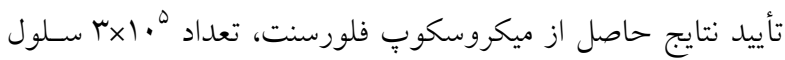

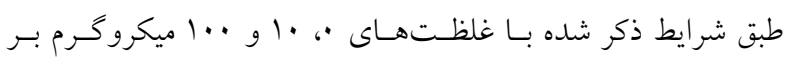

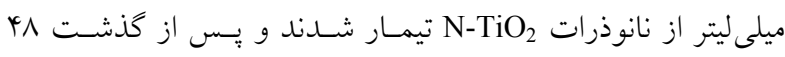

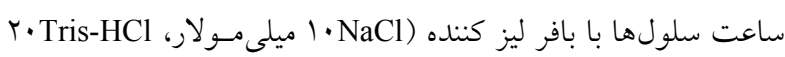

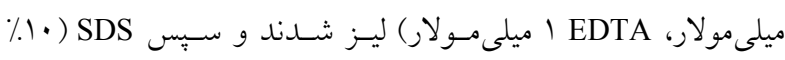

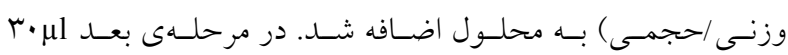
يروتئينازK به محلول حاصل اضافه شد و ميكروتيوبهـا در دمـاى

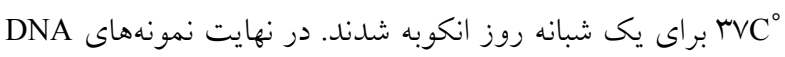

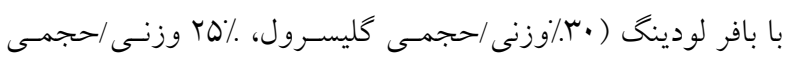

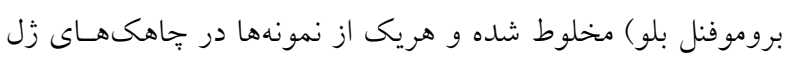

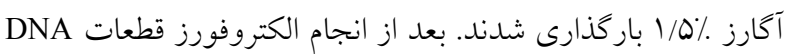
از هم جدا شده و مورد تجزيه و تحليل قرار خرفتند.

$$
\text { روش آمارى }
$$

تمامى دادههاى به دست آمده از اين يزوهش حاصل دو تـا سـهـ

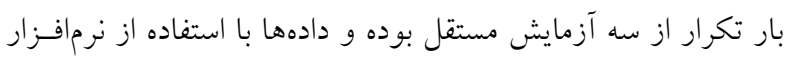

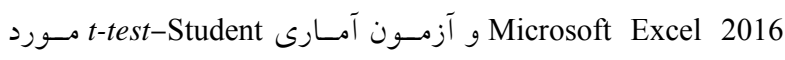

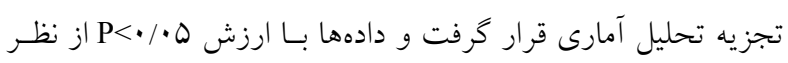
أمارى معنى دار درنظر خرفته شدند.

يافته ها

N-TiO

جدول ا: تعيين مشخصات نانوذرات N-TiO از طريق آناليزهاى DLS

\begin{tabular}{|c|c|}
\hline شرايط نانوذره در زمان تعيين سايز & سايز نانوذره (nm) \\
\hline نانوذره + آب & $V V \Psi \pm Y Y$ \\
\hline نانوذره + محيط كشت & $901 \pm 00$ \\
\hline 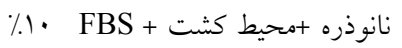 & $M \pm Y r$ \\
\hline
\end{tabular}


رشد سلولى به طور قابل توجهى كاهش مىيابـد، بـهـورىكـه بر

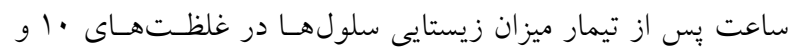

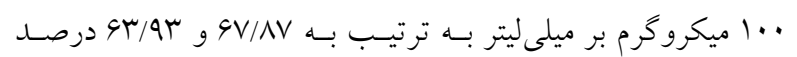

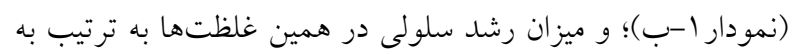

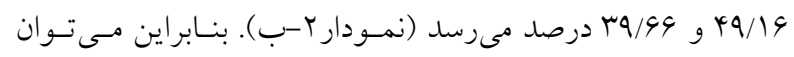
نتيجه كرفت كه نور مرئى قادر است نانوذرات N-TiO

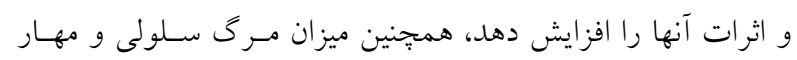
رشد القا شده توسط اين نانوذرات وابسته به زمان و غلظت بـوده و

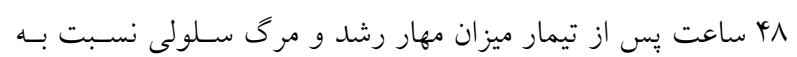

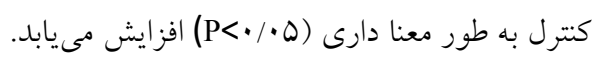

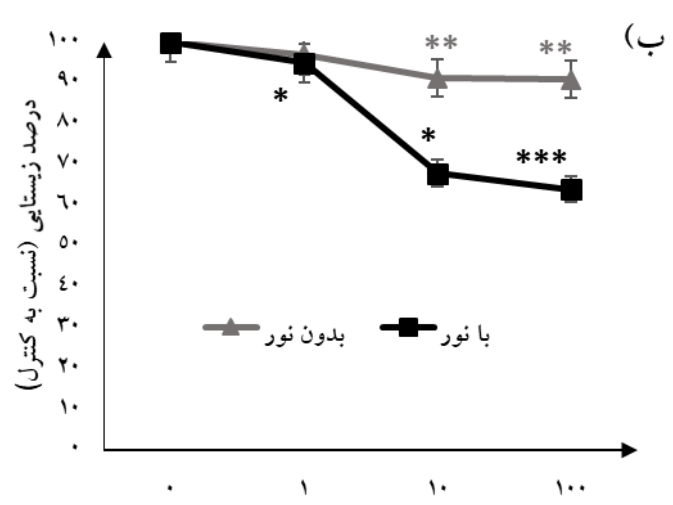

غلظت (ميكروگرم بر ميلى لبتر)
تاثير نانوذرات N-TiO بر روى زيستايى و رشد سلولهاى

MCF-7 آزمون دفع رنخ ترييان بلو براى محاسبه تغييرات ايجاد شده در ميزان زيستايى و رشد سلولهـاى MCF-7 تحــت تـأثير نـانوذرات تيتانيوم دىاكسيد دويه شده با نيتروزن انجام شد.

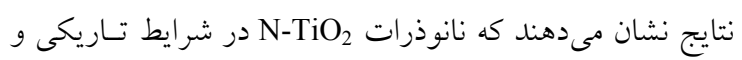

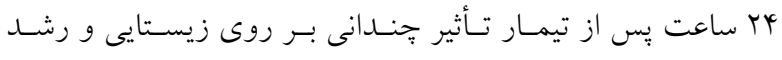

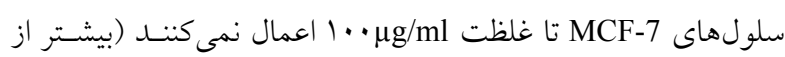

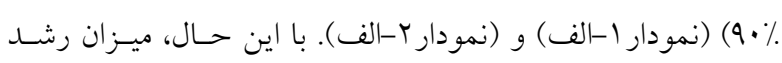

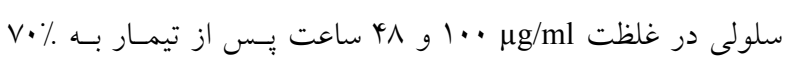
مىرسد (نمودار Y-ب). اما در حضور نور مرئسى ميـزان زيسـتايى و

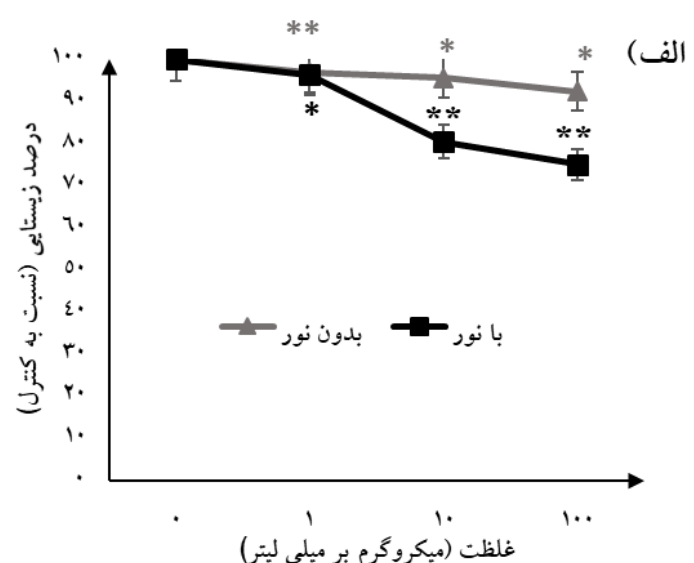

غلظت (ميكروگرم بر ميلى ليتر)

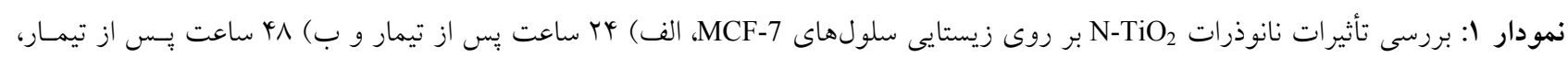
در حضور و غياب نور مرئى 0./
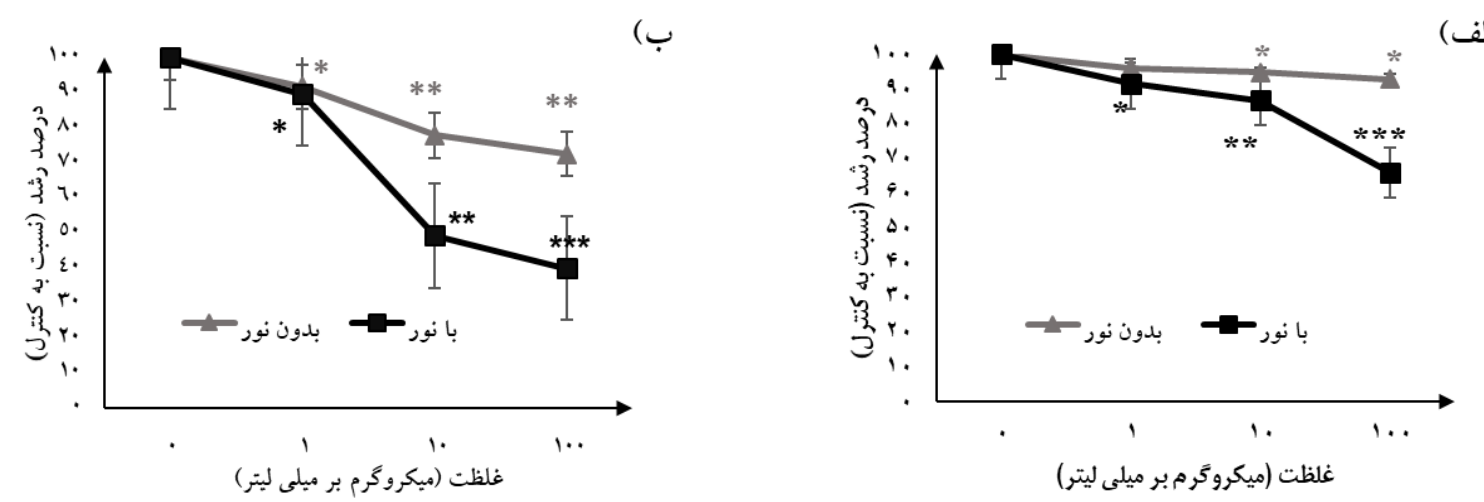

غلظت (ميكروتحر مبر ميلى ليتر)

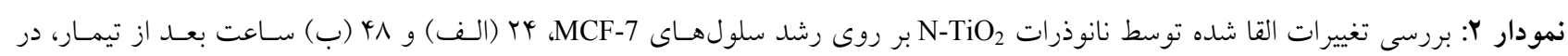
حضور و غياب نور مرئى 
تشخيص نوع مرگ سلولى از طريق ميكروسكوبٍ فلورسـنت و رنگآميزى آكريدين اورنج /اتيديوم برومايد

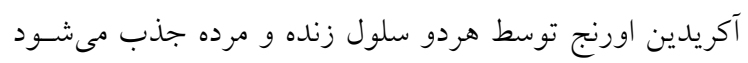

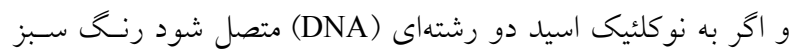
ايجاد مى كند، اكر به نو كلئيك اسيد تكى رشته متصـل شـود (RNA) رنغ قرمز ايجاد مىشود. اما اتيديوم برومايد تنها توسط سـلولهـاى التهاى مرده جذب مىشود و با اتصال به DNA رنغ قرمز متصاعد مى كند.

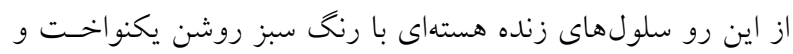
ساختار منظم دارند. رنخ هسته سلولهايى كـه در مرحلـه آيويتهوز

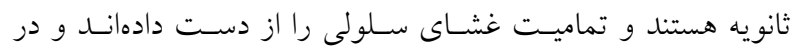

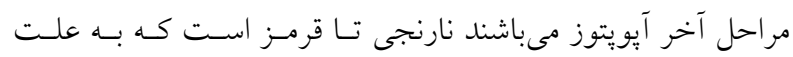

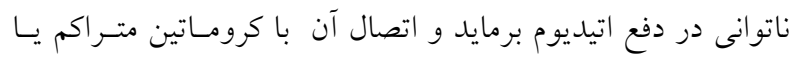

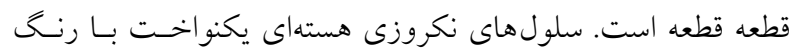

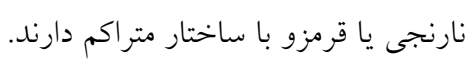

تغييرات ريختشناسى ايجاد شده پيس از تيمار با نانوذرات N-TiO

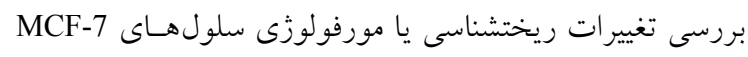

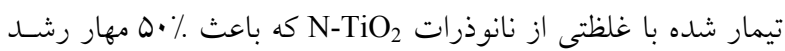

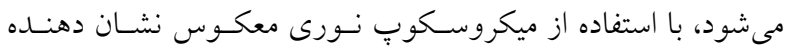
تغييرات در ظاهر سلولهاى تيمار شده مىباشد. سلولهاى MCF-7

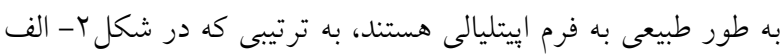

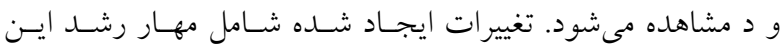

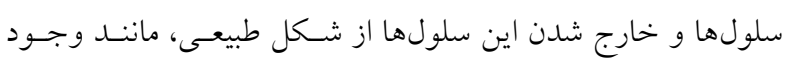

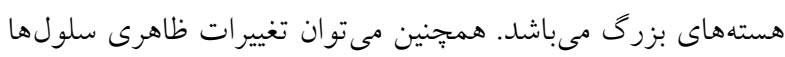

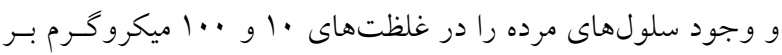

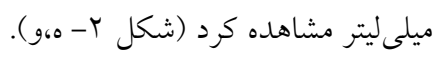
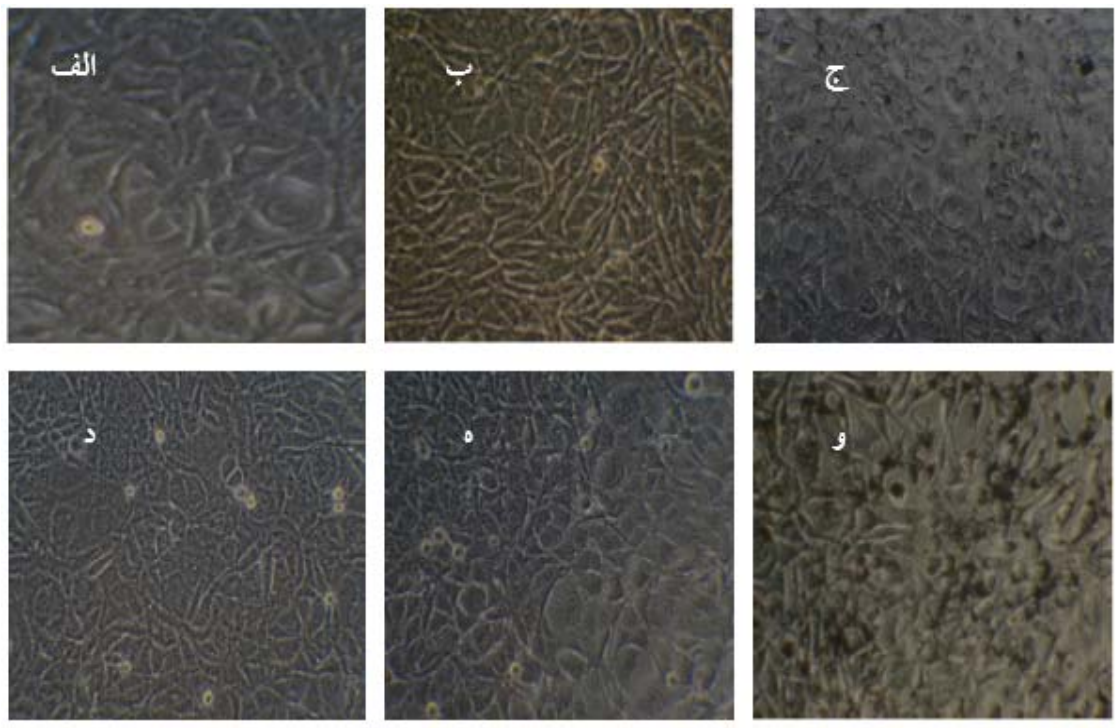

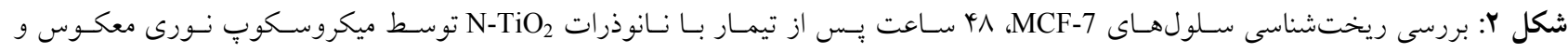

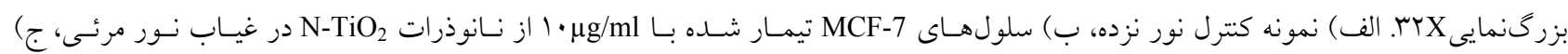

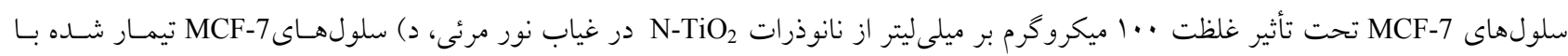

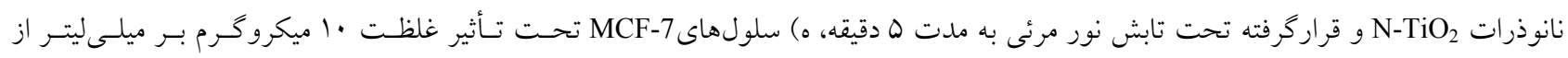

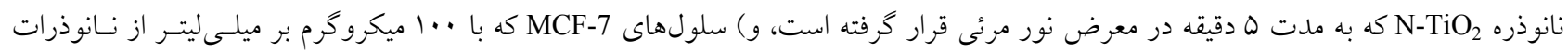
تيمار شده است و به مدت ه دقيقه در معرض نور مرئى قرار گرفته است. N-TiO 
(شكل r- الف و د). در غلطت · • ميكرو گرم بر ميلى ليتر در حضور

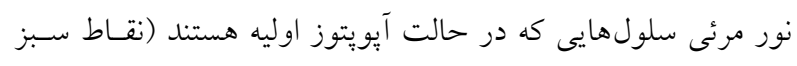

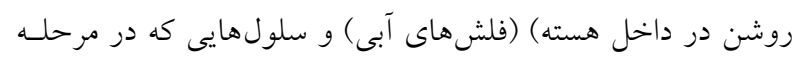

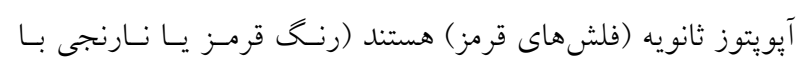

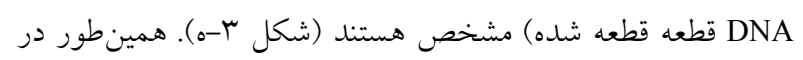
غلظت · ․ ميكرو گرم بر ميلى ليتر در حضور نور مرئى سلولهـايى كه در مرحلهى آيويتوز اوليه (فلشهاى آبى) هستند به ميزان كمتر و

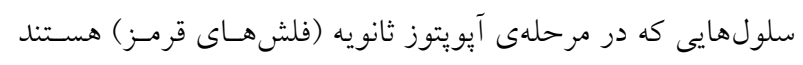
به ميزان بيشتر، قابل مشاهده مىباشند (شكل بـ م-و ).
براى بررسى اثرات آيويتوزى نانوذره N-TiO از ميكروسكوبٍ

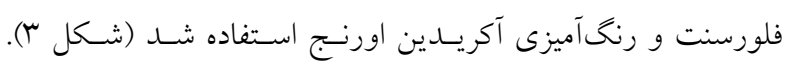

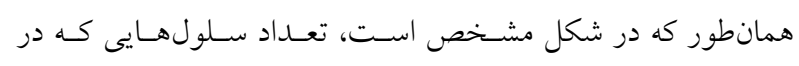

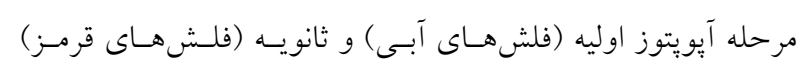

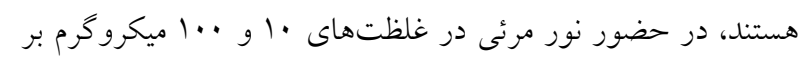
ميلى ليتر افزايش داشته است (شكل ب-ه، و ). همانطور كه مشاهده مىشود، نمونههاى كنتـرل نـور زده و نـور

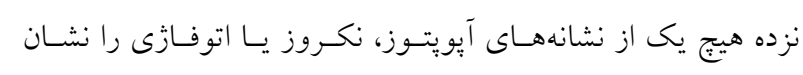

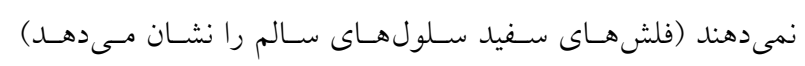
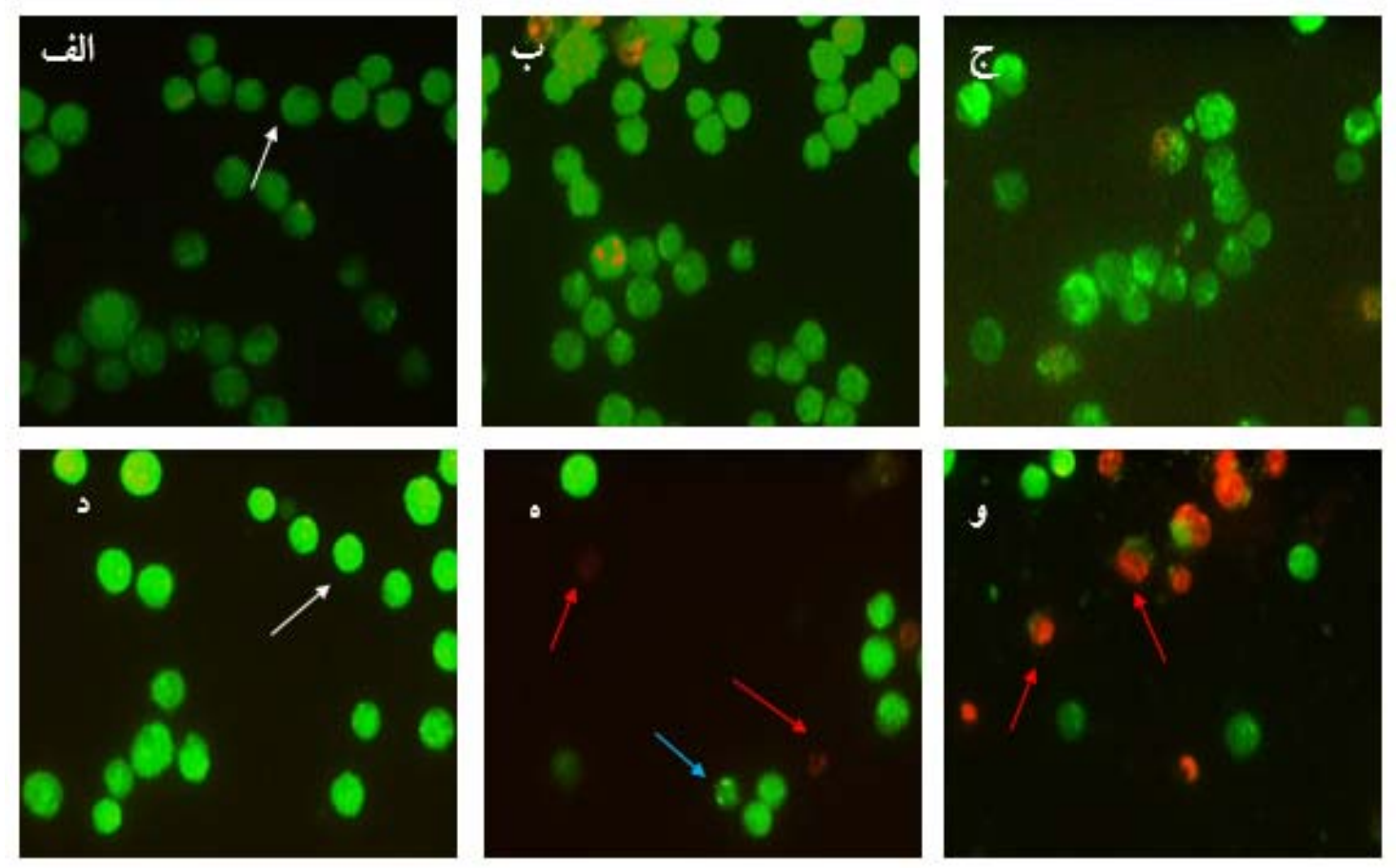

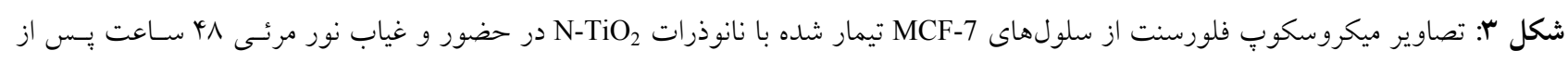
تيمار، بزرگنمايى

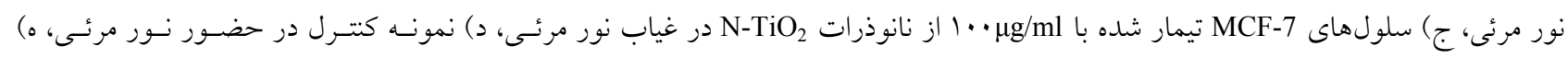

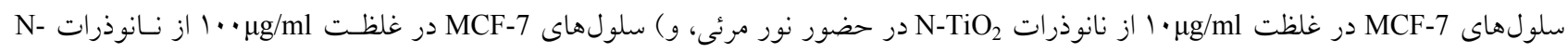

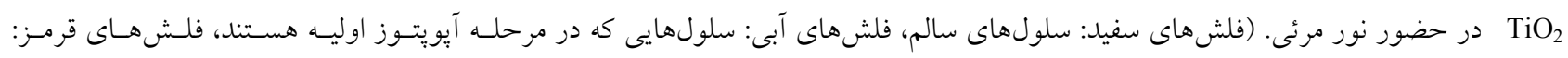
سلولهايى كه در مرحله آيويتوز ثانويه هستند). 


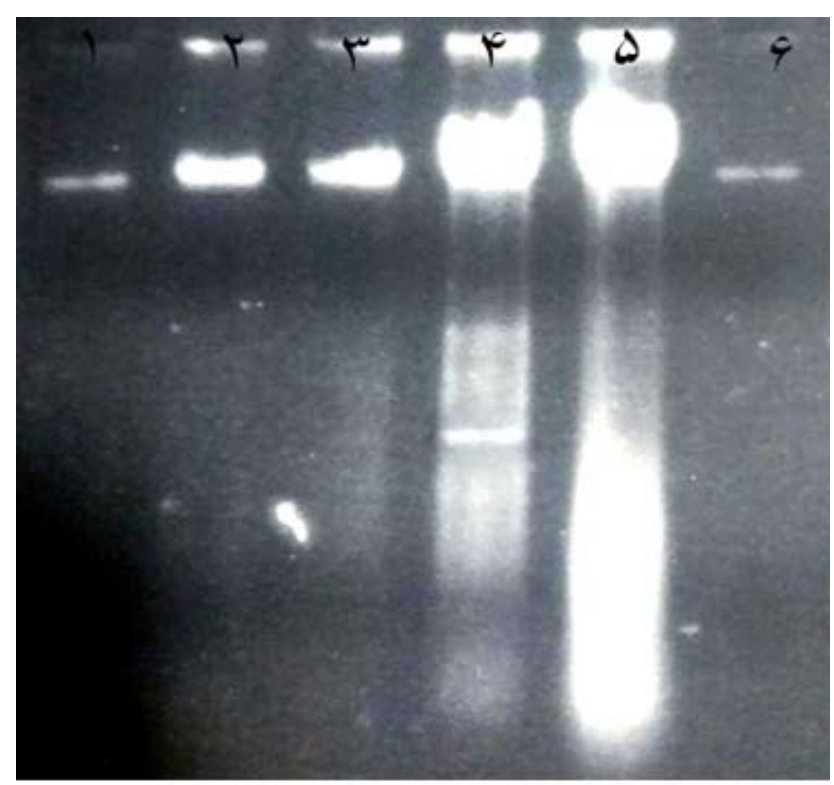

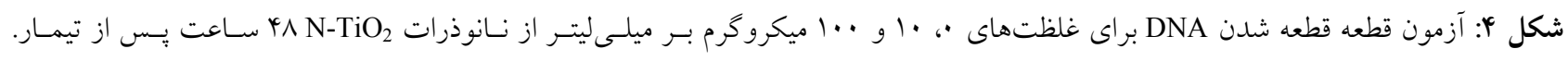

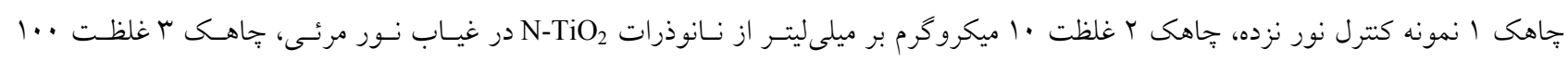

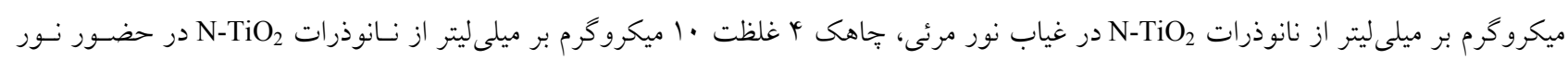

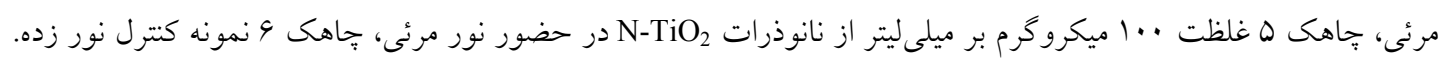

مرك سلولى باشد (شكل ثا، جاهك ه).

آزمون قطعه قطعه شدن DNA

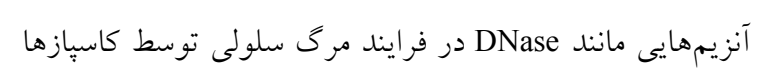

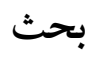

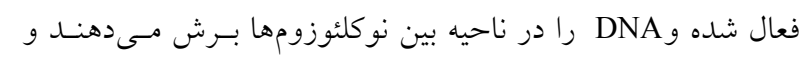

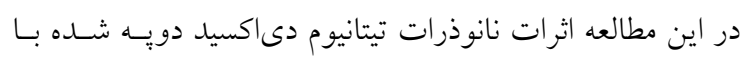

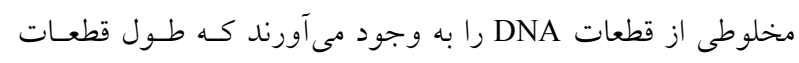

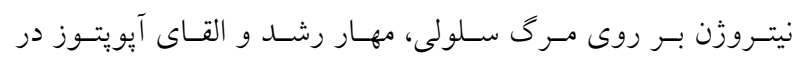

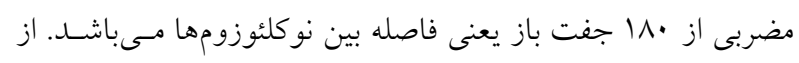

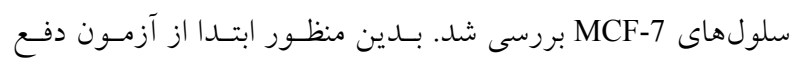

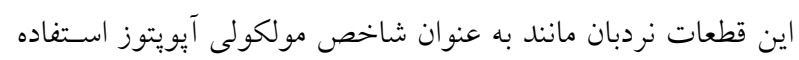

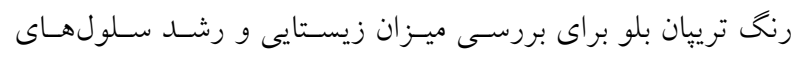

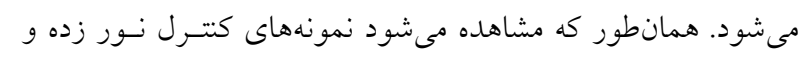

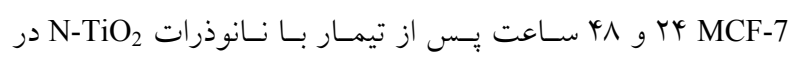

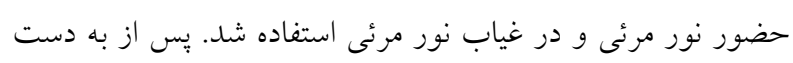

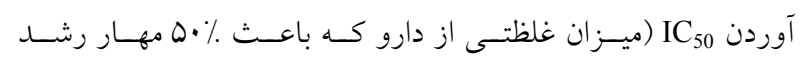

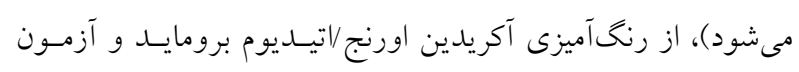

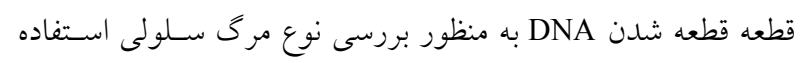

نتايج حاصل از آزمون دفع رنخ تريبان بلو نشان داد كه كسارايى نانوذرات N-TiO هنخامى كه تحت تابش نور مرئى قرار مى گيرنسا

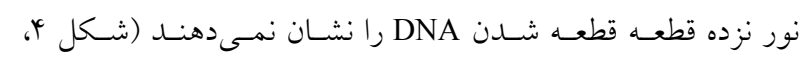

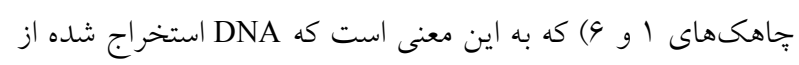

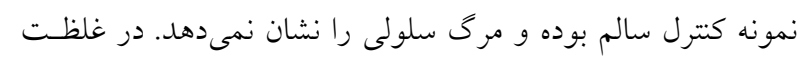

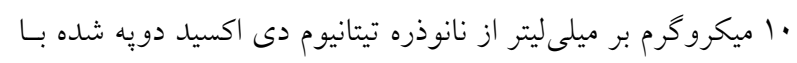

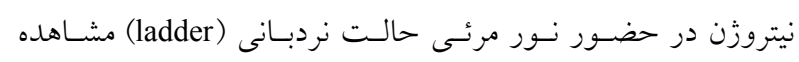

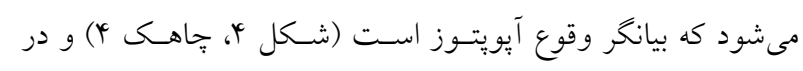

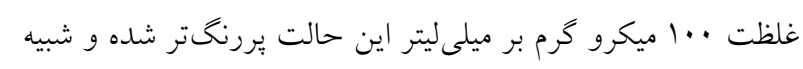
حالت لكه (Smear) مشاهده مىشود كه مى بواند بيانكر ميزان بيشتر 


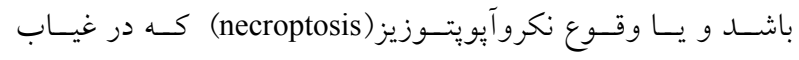

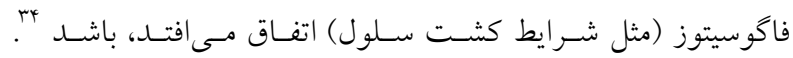
Lagopati سلولهاى اييتليالى سرطان يُسـتان رده MDA-MB-468 كـه بعـد از تيمار با نانوذرات N-TiO ايجاد مىشود به دليل افزايش بيان Bax و

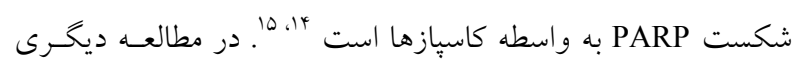
c و همكاران بيان كردند كه بيان بروتئينهـاى سـيتوكروم Murugan در سلولهاى MCF-7 تيمـار شــده بـا نـانوذرات N-TiO افـزايش

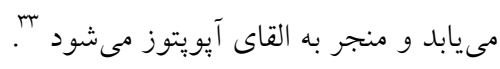

\section{نتيجه كيرى}

در اين مطالعه يتانسيل هاى ضد سرطانى نانوذرات تيتـانيوم دى-

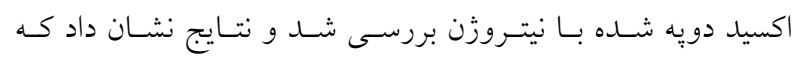
نانوذرات N-TiO تنها در حضور نور مرئى اثـرات مهـار رشـدى و القاى آيويتوز را در سلولهاى MCF-7 نشان دادند. همجنين در اين مطالعه نشان داده شد كه نانوذرات N-TiO قادر به القاى آيويتوز در رده سلولى MCF-7 است. با توجه به اين نتايج و نتايج حاصل از مطالعات صورت كرفتسه توسط محققان به منظور بررسى اثرات نانوذرات تيتـانيوم دىاكسيد

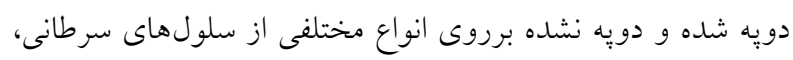

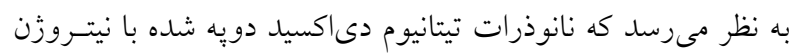

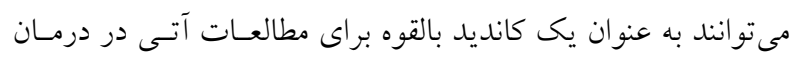
فتو كاتاليتيكى سرطان پِستان مورد توجه قرار بحيرند.

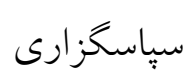

نو يسند كان مراتب قدردانى خود را از يزوهانسه بنيـاد ملى علـم

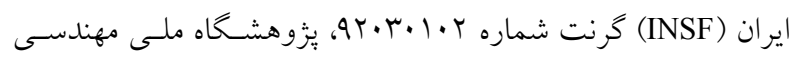
زنتيك و زيست فنـاورى و همجنــين دانشـعاه آزاد اسـلامى واحسـ تهران مركزى جهت حمايت اين كار ابراز مىدارند.
به ميزان قابل توجهى افزايش مى يابـــ. ايسن در حسالى اسـت كـه در

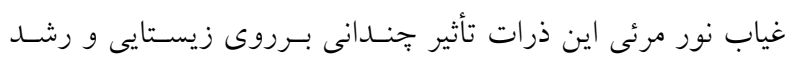
سلولهاى MCF-7 ندارند. نتايج مطالعات ما نشان داد كه تأثير ايسن

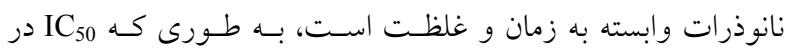

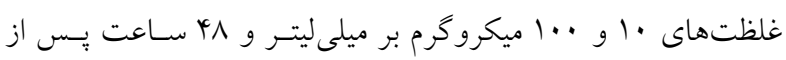

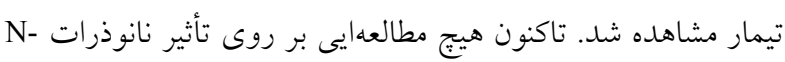

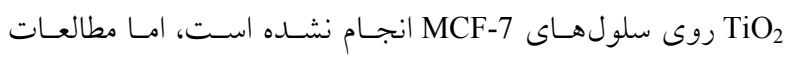

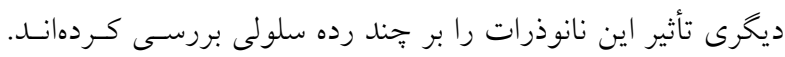
براى مثال Li و همكاران ميـزان سـميت نـانوذرات N-TiO را در حضور و در غيـاب نـور مرئسى مـورد ارزيـابى قـرار دادند. آنها دريافتند كه نمونههاى N-TiO كشندگى بهترى نسبت به $\mathrm{TiO}$ تحت تأثير نور مرئى دارند. بنابراين N-TiO

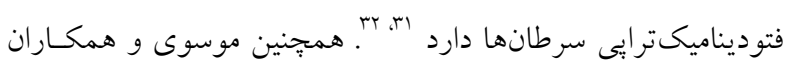
نشان دادند كه نانوذرات N-TiO در حضور نور مرئسى سـبب مهـار رشد و كاهش زيستائى در سلولهاى K562 مىشوند بو بـ به منظـور بررسى وقوع آيويتوز به دنبال تيمار سلولها بـا نـانوذرات

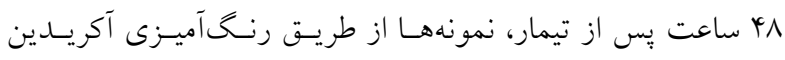

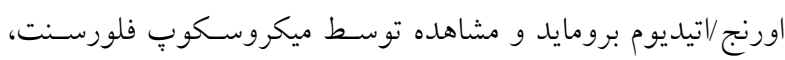

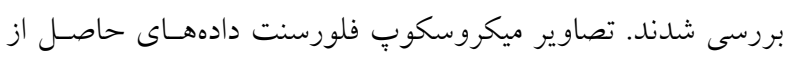
آزمون دفع رنگ تريبان بلو را تأييد كرد. به اين صورت كه بيشترين

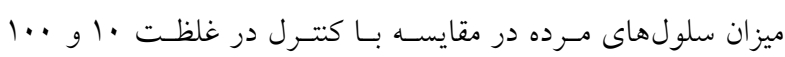
ميكرو گرم بر ميلى ليتر در حضور نور مرئى مشـاهده شـــ. در شـكل مئل

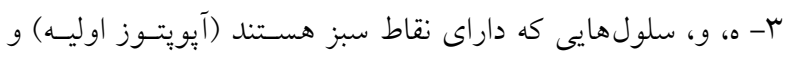

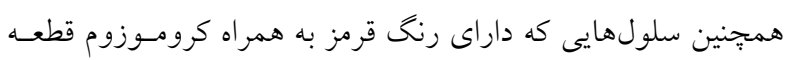

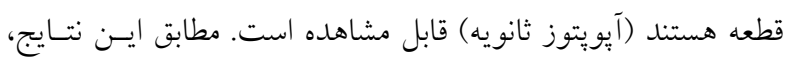

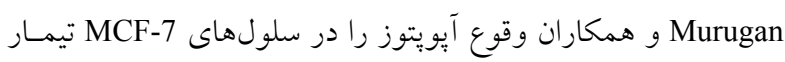
شده با نانوذرات TiO از طريق ميكروسكوبٍ فلورسنت نشان دادند

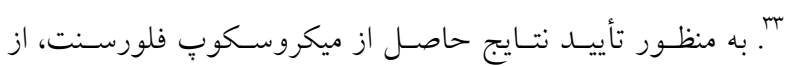
آزمون قطعه قطعه شدن DNA استفاده شد. الكوى قطعه قطعه شـدن

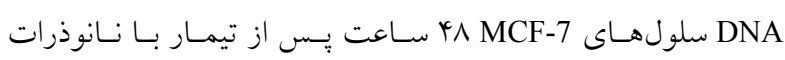
د-TiO 2 و در غلظت · (ladder)

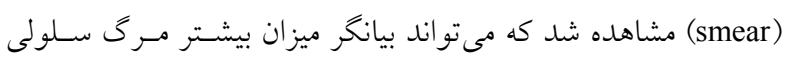




\section{References}

1. Rafiemanesh H, Mehtarpour M, Khani F, Hesami SM, Shamlou R, Towhidi F, et al. Epidemiology, incidence and mortality of lung cancer and their relationship with the development index in the world. J Thorac Dis 2016; 8(6): 1094-102.

2. Enayatrad M, Amoori N, Salehiniya H. Epidemiology and trends in breast cancer mortality in Iran. Iran J Public Health 2015; 44(3): 430-1.

3. Eccles SA, Aboagye EO, Ali S, Anderson AS, Armes J, Berditchevski $F$, et al. Critical research gaps and translational priorities for the successful prevention and treatment of breast cancer. Breast Cancer Res 2013; 15(5) : 92-29.

4. Sambi M, Haq S, Samuel V, Qorri B, Haxho F, Hill K, et al. Alternative therapies for metastatic breast cancer: multimodal approach targeting tumor cell heterogeneity. Breast Cancer (Dove Med Press). 2017;9:85-3

5. Lee JJ, Yazan LS, Abdullah CAC. A review on current nanomaterials and their drug conjugate for targeted breast cancer treatment. Int J Nanomedicine. 2017; 12: 2373-84.

6. Senkus E, Kyriakides S, Penault-Llorca F, Poortmans P, Thompson A, Zackrisson S, et al. Primary breast cancer: ESMO Clinical Practice Guidelines for diagnosis, treatment and follow-up. Ann Oncol. 2013; 24(suppl_6): $7-23$.

7. Provenzano E, Pinder SE. Modern therapies and iatrogenic changes in breast pathology. Histopathology. 2017;70(1):40-55.

8. Grobmyer SR, Zhou G, Gutwein LG, Iwakuma N, Sharma P, Hochwald SN. Nanoparticle delivery for metastatic breast cancer. Maturitas. 2012;73(1):19-26.

9. Jabir NR, Tabrez S, Ashraf GM, Shakil S, Damanhouri GA, Kamal MA. Nanotechnology-based approaches in anticancer research. Int J Nanomedicine. 2012;7:4391408.

10. Chidambaram M, Manavalan R, Kathiresan K. Nanotherapeutics to overcome conventional cancer chemotherapy limitations. J Pharm Pharm Sci 2011;(1)14:67-77.

11. Cuenca AG, Jiang H, Hochwald SN, Delano M, Cance WG, Grobmyer SR. Emerging implications of nanotechnology on cancer diagnostics and therapeutics. Cancer. 2006;107(3):459-66.

12. Rajh T, Dimitrijevic NM, Bissonnette M, Koritarov T, Konda V. Titanium dioxide in the service of the biomedical revolution. Chem Rev. 2014;114(19):10177216.

13. Jukapli NM, Bagheri S. Recent developments on titania nanoparticle as photocatalytic cancer cells treatment. J. Photochem. Photobiol. B, Biol. 2016;163:421-30.
14. Lagopati N, Kitsiou P, Kontos A, Venieratos P, et al. Photo-induced treatment of breast epithelial cancer cells using nanostructured titanium dioxide solution. J Photochem Photobiol A Chem. 2010;214(2): 215-23.

15. Lagopati N, Tsilibary E-P, Falaras P, Papazafiri $P$, Pavlatou EA, Kotsopoulou E, et al. Effect of nanostructured $\mathrm{TiO}_{2}$ crystal phase on photoinduced apoptosis of breast cancer epithelial cells. Int $\mathbf{J}$ Nanomedicine. 2014;9:3219-30.

16. Raliya R, Singh Chadha T, Haddad K, Biswas P. Perspective on nanoparticle technology for biomedical use. Curr Pharm Des. 2016;22(17):2481-90.

17. Yin ZF, Wu L, Yang HG, Su YH. Recent progress in biomedical applications of titanium dioxide. Phys Chem Chem Phys. 2013;15(14):4844-58.

18. Cai R, Hashimoto K, Itoh K, Kubota Y, Fujishima A. Photokilling of malignant cells with ultrafine $\mathrm{TiO}_{2}$ powder. Bull Chem Soc Jpn. 1991;64(4):1268-73.

19. Cai R, Kubota Y, Shuin T, Sakai H, Hashimoto K, Fujishima A. Induction of cytotoxicity by photoexcited $\mathrm{TiO}_{2}$ particles. Cancer Res. 1992;52(8):2346-8.

20. Huang N-P, Min-hua X, Yuan C-W, Rui-rong Y. The study of the photokilling effect and mechanism of ultrafine $\mathrm{TiO}_{2}$ particles on U937 cells. J Photochem Photobiol A Chem. 1997;108(2-3):229-33.

21. Zhang A-P, Sun Y-P. Photocatalytic killing effect of $\mathrm{TiO} 2$ nanoparticles on Ls-174-t human colon carcinoma cells. World J Gastroenterol. 2004;10(21):3191-3.

22. Park E-J, Yi J, Chung K-H, Ryu D-Y, Choi J, Park K. Oxidative stress and apoptosis induced by titanium dioxide nanoparticles in cultured BEAS-2B cells. Toxicol Lett. 2008;180(3):222-9.

23. Agostinis P, Berg K, Cengel KA, Foster TH, Girotti AW, Gollnick SO, et al. Photodynamic therapy of cancer: an update. CA Cancer J Clin. 2011;61(4):250-81.

24. Robertson CA, Evans DH, Abrahamse H. Photodynamic therapy (PDT): a short review on cellular mechanisms and cancer research applications for PDT. J. Photochem. Photobiol. B, Biol. 2009;96(1):1-8.

25. Banerjee AN. The design, fabrication, and photocatalytic utility of nanostructured semiconductors: focus on $\mathrm{TiO}_{2-}$ based nanostructures. Nanotechnol Sci Appl. 2011;4:3565 .

26. Gupta SM, Tripathi M. A review of $\mathrm{TiO}_{2}$ nanoparticles. Chin Sci Bull. 2011;56(16):1639-57.

27. Carp O, Huisman CL, Reller A. Photoinduced reactivity of titanium dioxide. Progress in solid state chemistry. 2004;32(1):33-177.

28. Asahi R, Morikawa T, Ohwaki T, Aoki K, Taga Y. Visible-light photocatalysis in nitrogen-doped titanium oxides. science. 2001;293(5528):269-71. 
29. Moosavi MA, Sharifi M, Ghafary SM, Mohammadalipour Z, Khataee A, Rahmati M, et al. Photodynamic $\mathrm{N}-\mathrm{TiO}_{2}$ nanoparticle treatment induces controlled Ros-mediated autophagy and terminal differentiation of leukemia cells. Sci Rep. 2016;4(6):34413-23.

30. Khataee A, Zarei M, Moradkhannejhad L, Nourie S, Vahid B. Nitrogen doping of commercial $\mathrm{TiO}_{2}$ nanoparticles for enhanced photocatalytic degradation of dye under visible light: Central composite design approach. Adv Chem Lett. 2013;1(1):24-31.

31. Li Z, Mi L, Wang PN, Chen JY. Study on the visiblelight-induced photokilling effect of nitrogen-doped $\mathrm{TiO}_{(2}$ ,nanoparticles on cancer cells. Nanoscale Res Lett.
2011;6(1):356-62.

32. Li Z, Pan X, Wang T, Wang P-N, Chen J-Y, Mi L. Comparison of the killing effects between nitrogen-doped and pure $\mathrm{TiO}_{2}$ on HeLa cells with visible light irradiation. Nanoscale Res Lett. 2013;8(1):96-2.

33. Murugan K, Dinesh D, Kavithaa K, Paulpandi M, Ponraj T, Alsalhi MS, et al. Hydrothermal synthesis of titanium dioxide nanoparticles: mosquitocidal potential and anticancer activity on human breast cancer cells (MCF-7). Parasitol Res. 2016;115:1085-96.

34. Mahassni SH, Al-Reemi RM. Apoptosis and necrosis of human breast cancer cells by an aqueous extract of garden cress (Lepidium ativum) seeds. Saudi J Biol Sci. 2013;20(2):131-9. 